\title{
Potential Toxic Elements Contamination of Soils in O'Kiep, an Arid Region of Namaqualand, South Africa
}

\author{
I.G. Erdogan ${ }^{\mathrm{a}, \mathrm{b}, \mathrm{c}}$, E. Fosso-Kankeu ${ }^{\mathrm{a}^{*}}$, S.K.O. Ntwampe ${ }^{\mathrm{b}}$, F.B. Waanders ${ }^{\mathrm{a}}$, N. Hoth ${ }^{\mathrm{d}}$ and A Rand ${ }^{\mathrm{b}}$
}

\begin{abstract}
The aim of this study was to evaluate the geochemical background and spatial distribution patterns of selected potential toxic elements (PTEs) in ten sub-surface soil samples $(n=10)$ collected in the former copper mining area, O'Kiep. The major oxides and PTEs in the samples were identified and measured using X-ray fluorescence and X-ray diffractometer. The contaminated soils were compared to prestige soil and Soil Screening Values for All Land-Uses Protective of the Water Resource - references which can elucidate PTE contamination. The examined soils showed a high variability in the PTEs concentrations. O'Kiep soils show some degree of contamination with an average low pH of 3.5 and an Eh of $520 \mathrm{mV}$. The most abundant PTEs in the soils were $\mathrm{S}>\mathrm{Cu}>\mathrm{F}>\mathrm{Mn}>\mathrm{Cl}>\mathrm{Zn}>\mathrm{Cr}>$ $\mathrm{V}>\mathrm{Pb}>\mathrm{Ni}>\mathrm{Co}$. The soil type in downstream was classified as silt with a clay content of $1.1 \%$. The mineralogical study of the soils revealed minerals such as Alumino-silicates, Ca-silicates and Mg-silicates aggregates, with a strong similarity between the downstream and upstream samples from the mining area, while the midstream only differred by the presence of hematite. The median values of oxides contents in soils follow a decreasing order as: $\mathrm{SiO}_{2}>\mathrm{Al}_{2} \mathrm{O}_{3}>\mathrm{Fe}_{2} \mathrm{O}_{3}>\mathrm{K}_{2} \mathrm{O}$. Furthermore, factors that influence the distribution and migration of PTEs in soils were largely identified as mine waste heaps and slime dams further north from the sampling sites. Excessive concentration of PTEs in O'Kiep's soils may lead to elevated potential risks to human health and the local environment. The material of mine waste heaps is very fine and can easily migrate with wind and water erosion. Therefore, further risk assessment analyses of mine waste heaps and the mine are required in O'Kiep.
\end{abstract}

Keywords - Arid region, Copper mining, Potential Toxic Elements (PTEs), O'Kiep, Soil Contamination.

Manuscript received October 03, 2018. The authors are grateful to the sponsor from the North-West University, from Cape Peninsula University of Technology (CPUT), University Research Fund (Grant no. URF RY12) and the National Research Foundation (NRF) in South Africa.

${ }^{\mathrm{a} W a t e r}$ Pollution Monitoring and Remediation Initiatives Research Group and the School of Chemical and Minerals Engineering at the North-West University, South Africa. ${ }^{\mathrm{b}}$ Bioresource Engineering Research Group (BioERG), Department of Biotechnology, Cape Peninsula University of Technology, Cape Town, South Africa

${ }^{c}$ Department of Chemical Engineering, Cape Peninsula University of Technology, Cape Town South Africa

${ }^{\mathrm{d}}$ Institute of Mining and Special Civil Engineering, Technische Universität Bergakademie Freiberg, Saxony, Germany

\section{INTRODUCTION}

Worldwide, soil contamination has increasingly been studied by various researchers including in South Africa (SA) with the support of environmental protection organisations [1]. In SA, some studies have been conducted on metals pollution in gold [2], coal [3] and diamond [4] mining areas. However, minimal studies have been reported in potential toxic elements (PTEs) of soil in copper mining areas especially in O'Kiep, SA. The area is the oldest formally proclaimed copper mining area in SA [5]. Soils can be a reservoir of large quantities of PTEs from several sources including municipal and industrial waste such as mining gangue [6]. However, the physico-chemical characteristics of the soil is a vital indicator which influences the dispersion of PTEs in contaminated areas [7]. Contaminated soils including arable land are no longer suitable for farming, since they are unable to yield healthy crops especially in O'Kiep. O'Kiep soils have been described as being highly polluted, which is indicative of significant environmental damage related to the presence of PTEs in the organic fraction, bound forms [8], with some metal recycling occurring as a result of organic matter decomposition. Soluble minerals are also being mobilised through interaction of carbonic acid and water, while relatively insoluble minerals such as quartz $\left(\mathrm{SiO}_{2}\right)$ disintegrate as finer particles and the end result of weathering is soil [9]. The persistent wind in the area was also considered a health problem in this town [10].

In historic mining areas, soils are usually enriched with PTEs. These PTEs are from geochemical processes, weathering of mineralised zones and from different mining activities including disposal of mine wastes $[11,12]$. According to previous reports, the mineralogical composition of soils from O'kiep mining area includes bismuthinite, bornite, chalcocite, chalcopyrite, covellite, galena, ilmenite, magnetite, molybdenite pentlandite, pyrite, pyrrhotite, quartz, scheelite, sillimanite, sphalerite and thorite $[13,14]$. In some warm climate areas including O'Kiep, where chemical weathering dominates, soils tend to be richer in clay - resulting in the localisation entrapment of some PTEs. The closed mining areas are often a source of severe environmental problems caused by the mobility of PTEs and consequently the formation of acid mine drainage [15], with chemical and biochemical reactions proceeding fastest under warm conditions [16]. Before rehabilitation of soils in historic mining areas, it is essential to establish geochemical 
characteristics of metals in the soils.

The bioavailability and mobility of PTEs in surface soils was examined in O'Kiep by Moncho [17] with application of sequential extraction analyses. Characterising the factors affecting bioavailability, leaching and toxicity of metals and metalloids in soil to water sources is of paramount importance. Although, metals and metalloids are significant natural components of all soils where their presence in the mineral fraction comprises a storage of potentially-mobile species that have a negative influence on soil geochemistry and groundwater quality [18, 19].

In SA, attention has been drawn to the mining industries and its adverse effects on the environment and posing potential health risk to communities such as those at O'Kiep. Copper contamination of the whole region is the result of processing of copper ores from a closed metalliferous mine. Produced waste material from this mine was stored in the numerous heaps and in the tailing ponds. Rehabilitation of the mine including copper oxide ore dumps and extensive slime dams remains a challenge and as part of the program are earmarked for redistribution and reprocessing [10]. The present past land use of this site is well known for copper mining. However, the mining activity ceased in 2007 and the area has been under slow but systematic rehabilitation ever since [10]. The mineralogy and geochemistry of this soil was never examined. The main objectives of this study were: 1] to characterise spatial distribution of trace elements in soils of the historic O'Kiep copper mining area in Namaqualand; and 2] to evaluate site-specific geochemical background concentrations of these elements in the mine soils as the geochemical and mineralogical studies of the soils will elucidate contamination by PTEs such that effective reclamation and remediation actions are developed.

\section{MATERIALS AND METHODS}

\section{A. Sample collection}

Soil samples $(\mathrm{n}=11)$ were collected in O'Kiep [29 $35^{\prime} 45^{\prime \prime} \mathrm{S}$, $\left.17^{\circ} 52^{\prime} 51^{\prime \prime} \mathrm{E}\right]$ ( $\left.38.63 \mathrm{~km}^{2}\right)$ located in the Namaqualand region, Northern Cape, SA. This area is described as arid with a temperature of $37^{\circ} \mathrm{C}$ with an estimated evaporation rate which greatly exceeds the precipitation, highlights both the aridity and water scarcity of the area $[20,21]$. This high evaporation rate, which significantly exceeds the rainfall, highlights water scarcity and the dryness of the area. Soil samples were collected as per field soil sampling guidelines by mean of haphazard, judgement, probability and analysis of soils method described by Gregorich and Carter [22] and Schoeneberger [23]. The sampling site was cleared of litter, of living plants and surface rocks prior to sample collection. The sub-soil was sampled from a spolic and transportic soil layer at a subsurface depth of approximately 30 to $100 \mathrm{~cm}$ [24]. All samples were collected in August 2017 during the wet season and sampling points were marked using a Global Positioning System (GPS) as shown in Fig. I.

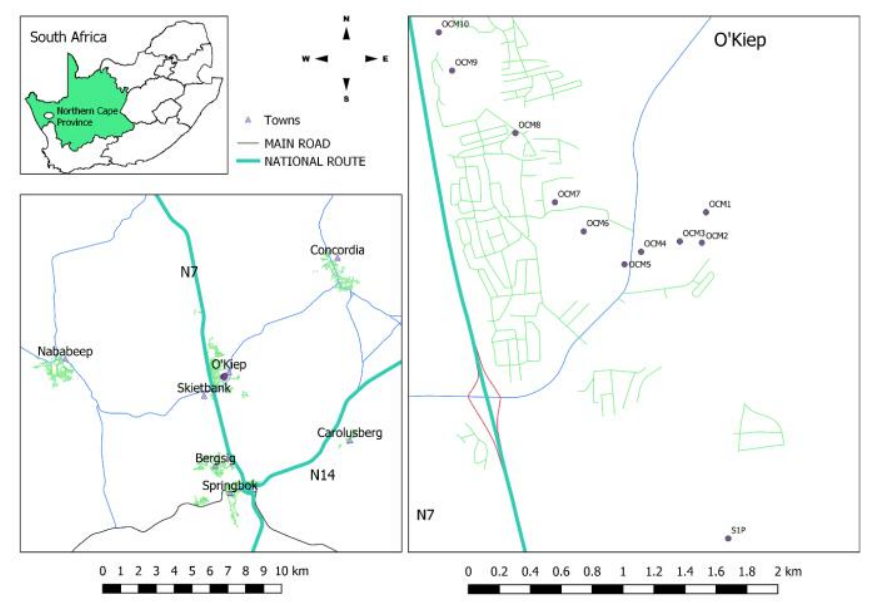

Fig.1. Location of study area and sampling points drawn using drawn using Geological maps were generated using Quantum GIS software (v. 2.18.11) and data from National Geo-Spatial Information (NGI), a component of the Department of Rural Development and Land Reform, South Africa.

To assess soil samples variation, all samples were taken every 150 to $200 \mathrm{~m}$ from upstream to downstream area of the mining site. A total of ten potentially contaminated soils were collected namely, OCM1 and OCM2, samples representing a composite of four sub-samples collected in a $5 \mathrm{~m}$ x $5 \mathrm{~m}$ grid, upstream; [OCM3, OCM4, OCM5, OCM6 (near mine waste heaps)] (midstream) and OCM7, OCM8, OCM9 and OCM10 (downstream) were compared to pristine soil sample (S1P) (prestige) collected $5 \mathrm{~km}$ away from sampling site by means of a Draper 24414 steel auger [23, 25, 26]. Subsequently, about $1 \mathrm{~kg}$ was sampled, then homogenised by mortaring into a composite sample which was air-dried and sieved using a 2-mm polyethylene with fraction remaining on the sieve being weighed to determine the percentage of coarse fragments. The samples were bagged into sterile polythene zipper top bags to prevent contamination and transported to the laboratory for further analysis.

\section{B. Soil Sample Analyses}

\section{1) Soil type and texture}

As According to soil guide of SA, the soil texture and type in arid regions consist of different principle of soils with special sub-soil characteristics relating to pedogenic accumulation and having an orthic topsoil characteristics comprising of groups namely calcic and silicic constituents [27].

\section{2) Paste preparation for $\mathrm{pH}$ and Redox (Eh) determination}

Saturated pastes created by slurrification of the soil and water using a 1:2 ratio, were prepared with soils from each of the eleven sub-soil sample composites. The pastes were prepared in $500 \mathrm{~mL}$ polypropylene bottles according to Sobek (1978). The soils were allowed to wet by capillary action before being stirred to a thin paste with a spatula. The spatula was rinsed with deionised water before stirring each sample. Prior to the measurement of $\mathrm{pH}$ and Eh using an EXSTIK II® EC500, the instrument was calibrated. 


\section{3) Laboratory Methods}

The soil samples were analysed at the University of Cape Town, Department of Geological Sciences, SA, using X-ray fluorescence (XRF) and X-ray diffractometer. The details of sample preparation, instrumental techniques for each method are described by Beckhoff [29] and Compton [30].

\section{RESULTS}

The abundant major oxides of soil samples are presented in Fig. II.

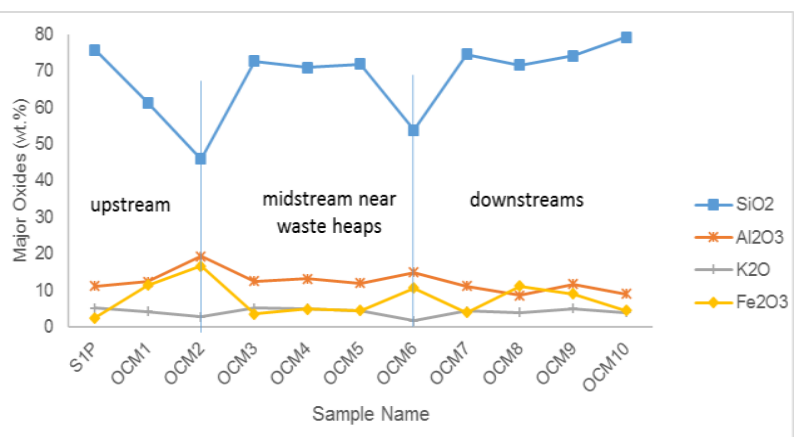

Fig. 2. Major Oxides at various sampling points

TABLE I: POTENTIAL TOXIC ELEMENTS COMPARED WITHIN SOIL SCREENING VALUES (SSV) ADOPTED FROM WASTE ACT 59 OF 2008.

\begin{tabular}{|c|c|c|c|c|c|c|c|c|c|c|c|c|}
\hline \multirow{2}{*}{$\begin{array}{c}\text { Sample } \\
\text { No. }\end{array}$} & & \multirow[t]{2}{*}{$\mathrm{Pb}$} & \multirow[t]{2}{*}{$\mathrm{Zn}$} & \multirow[t]{2}{*}{$\mathrm{Cu}$} & \multirow[t]{2}{*}{$\mathrm{Ni}$} & \multirow[t]{2}{*}{ Co } & \multirow[t]{2}{*}{$\mathrm{Mn}$} & \multirow[t]{2}{*}{$\mathrm{Cr}$} & \multirow[t]{2}{*}{ v } & \multirow[t]{2}{*}{$\mathrm{F}$} & \multirow[t]{2}{*}{ s } & \multirow[t]{2}{*}{$\mathrm{Cl}$} \\
\hline & & & & & & & & & & & & \\
\hline & Streams & $\mathrm{mg} / \mathrm{kg}$ & $\mathrm{mg} / \mathrm{kg}$ & $\mathrm{mg} / \mathrm{kg}$ & $\mathrm{mg} / \mathrm{kg}$ & $\mathrm{mg} / \mathrm{kg}$ & $\mathrm{mg} / \mathrm{kg}$ & $\mathrm{mg} / \mathrm{kg}$ & $\mathrm{mg} / \mathrm{kg}$ & $\mathrm{mg} / \mathrm{kg}$ & $\mathrm{mg} / \mathrm{kg}$ & $\mathrm{mg} / \mathrm{kg}$ \\
\hline S1P & & 30 & 21 & 9 & $<5$ & $<5$ & 248 & 63 & 39 & 640 & 308 & 136 \\
\hline OCM1 & \multirow{2}{*}{ 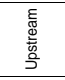 } & 42 & 49 & 3445 & 26 & 15 & 270 & 81 & 88 & 902 & 9282 & 125 \\
\hline OCM2 & & 232 & 168 & 5460 & 175 & 78 & 362 & 139 & 124 & 1684 & 7907 & 145 \\
\hline \multicolumn{2}{|c|}{ Av. } & 137 & 109 & 4453 & 101 & 46.5 & 316 & 110 & 106 & 1293 & 8595 & 135 \\
\hline OCM3 & \multirow{4}{*}{ 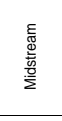 } & 41 & 40 & 391 & 7 & $<5$ & 273 & 42 & 50 & 581 & 792 & 114 \\
\hline OCM4 & & 43 & 65 & 301 & 16 & 7 & 233 & 61 & 72 & 803 & 1549 & 119 \\
\hline OCM5 & & 30 & 55 & 218 & 13 & 7 & 355 & 54 & 58 & 833 & 1094 & 145 \\
\hline OCM6 & & 15 & 104 & 89 & 63 & 47 & 1889 & 223 & 166 & 3550 & 1035 & 204 \\
\hline \multicolumn{2}{|c|}{$A v$. } & 53.2 & 74.5 & 1090 & 39.9 & 26.9 & 613 & 98.0 & 90.4 & 1412 & 2613 & 143 \\
\hline OCM7 & \multirow{4}{*}{ 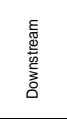 } & 32 & 63 & 591 & 27 & 10 & 353 & 58 & 63 & 665 & 687 & 116 \\
\hline OCM8 & & 122 & 367 & 935 & 47 & 16 & 386 & 84 & 53 & 662 & 790 & 118 \\
\hline OCM9 & & 28 & 31 & 25 & 0 & $<5$ & 254 & 46 & 51 & 642 & 706 & 121 \\
\hline OCM10 & & 29 & 36 & 460 & 25 & $<5$ & 197 & 50 & 37 & 471 & 528 & 108 \\
\hline \multicolumn{2}{|c|}{ Av. } & 52.8 & 124.3 & 503 & 24.8 & 13.0 & 298 & 59.5 & 51 & 610 & 678 & 116 \\
\hline \multicolumn{2}{|c|}{ SSV } & 20 & 240 & 16 & 91 & 300 & 740 & 6.5 & 150 & 30 & 4000 & 12000 \\
\hline
\end{tabular}

\section{DISCUSSION}

\section{A. Paste and leachates physical parameters}

The O'Kiep soil samples were dark brown in colour, weakly altered with an average paste $\mathrm{pH}$ of 3.4 determined to be fairly acidic. This was attributed to the presence of sulphidic minerals in the host rock that was undergoing oxidation thus acidifying the paste to sulphuric acid. However, the presence of $\mathrm{pH}$ buffering minerals such as Alumino-silicates, Ca-silicates and $\mathrm{Mg}$-silicates in such soil samples plays a significant role in mitigating the effects of acidic forming constituents and slurried leachates $[32,33]$. As expected the measured paste Eh values were higher in the all soil sample with an Eh of $518 \mathrm{mV}$ (max) being indicative of a highly oxidative environment. The soil redox potential and $\mathrm{pH}$ directly and indirectly influences all chemical processes undergone by a soil sample, and consequently, it can also determine the behaviour of PTEs in that soil sample. The combined effect of $\mathrm{pH}$ and Eh on the mobility of PTEs is complex and is highly species specific. The solubility of the PTEs that can occur as free hydrated cations generally increases with a decreasing $\mathrm{pH}[34,35]$, which will facilitate their mobility due to an increased concentration gradient.

\section{B. Major Oxides and Potential Toxic Elements}

The pristine soil (S1P) had a sandy texture (2.5 - 5.4 \%clay) with the clay including quarts, microcline, muscovite-2M albite and calcian. The average $\mathrm{pH}$ and Eh values of S1P was 8.1 and $178 \mathrm{mV}$, respectively. These Eh values indicated that S1P might have been slightly contaminated due to the accumulation processes of $\mathrm{Fe}^{3+}$ and $\mathrm{S}^{2-}$, even at distances far away from the source [36], which was attributed to wind conditions with contamination being via air deposition, as the S1P had a high PTEs concentration (mg/kg): F (640), $\mathrm{Cr}(63)$ and $\mathrm{Pb}(30)$, values which were not within Soil Screening Values (SSV) ascribed to a PTE free soil as defined by Waste Act 59 (200). The most abundant oxides were (wt\%): $\mathrm{SiO}_{2}(75.8)>\mathrm{Al}_{2} \mathrm{O}_{3}$ (11.2) >, $\mathrm{K}_{2} \mathrm{O}$ (5.08), and $\mathrm{Fe}_{2} \mathrm{O}_{3}$ (2.41). However, it was noticed that other PTEs such as $\mathrm{Zn}, \mathrm{Cu}, \mathrm{Ni}, \mathrm{Co}, \mathrm{Mn}, \mathrm{V}, \mathrm{S}$ and $\mathrm{Cl}$, were all within the SSV - an observation attributed to the absence of industrial activity in the location where S1P sample was collected, as further evidenced by the high $\mathrm{pH}(8.1)$ and the relatively low $\mathrm{S}$ content; an indication that acid-forming potential is probably low for the sample [37].

The composite sample OCM1 (source) which was within a $100 \mathrm{~m}$ distance of sampling point (OCM2) from the closed metalliferous mine, both defined as upstream in Table I, Fig. 1. OCM1 showed average $\mathrm{SiO}_{2}$ of $63.1 \mathrm{wt} \%$ (high), which increased in the upstream and downstream up to $72.7 \mathrm{wt} \%$ and $79.3 \mathrm{wt} \%$, respectively due to the presence of oxide minerals and sulphidic silicate that are present in several forms in O'Kiep [32]. Also, the high $\mathrm{SiO}_{2}$ content indicated active degradation including weathering of silicate minerals [38]. Localised hydrothermal alteration of hypersthene around sulphide grains is a conspicuous feature in altered host rock. On the other hand, oxides such as $\mathrm{Fe}_{2} \mathrm{O}_{3}, \mathrm{MgO}$ and $\mathrm{CaO}$ present in all the soil samples are usually degraded via mineral carbonation mechanisms [32, 38]. Ca-silicates comprise minerals such as albite, calcian, anorthite and sodian while $\mathrm{Mg}$-silicates include phlogopite-1M and serpentine while Fe-silicates include goethite [32]. Also, Alumino-silicates such as microcline, orthoclase and microcline were also detected upstream. Furthermore, on the surface, the oxide ore comprised of azurite, chrysocolla and malachite; hence up to $4453 \mathrm{mg} / \mathrm{kg}$ (average) of $\mathrm{Cu}$. However, the OCM1 displayed pyrrhotite-chalcopyrite ore characteristics similar to the classic magmatic mafic to ultramafic copper-nickel cobalt bodies [10]. Another observation was (see Table I) the presence of $\mathrm{Fe}_{2} \mathrm{O}_{3}, \mathrm{Al}_{2} \mathrm{O}_{3}, \mathrm{~K}_{2} \mathrm{O}$ and $\mathrm{Fe}_{2} \mathrm{O}_{3}$, which are normally formed during weathering process and/or events [38].

All measured PTEs in the upstream samples, i.e. $\mathrm{Pb}, \mathrm{Zn}, \mathrm{Cu}$, 
$\mathrm{Ni}, \mathrm{Co}, \mathrm{Mn}, \mathrm{Cr}, \mathrm{V}, \mathrm{F}, \mathrm{S}$ and $\mathrm{Cl}$, were present in high concentrations (mg/kg): 137, 109, 4453, 101, 46.5, 316, 110, 106, 1293, 8595 and 135, respectively. Clifford and Barton [39] reported that O'Kiep's soil is rich in bornite $\mathrm{Cu}_{5} \mathrm{FeS}_{4}$; as evidenced by the high concentration values of $\mathrm{S}$ and $\mathrm{Cu}$. From the literature reviewed, it was reported that distance from the pollution source and weather-related matters, play significant roles in the exposure to metalloids and metals [40]. PTE concentrations in the upstream showed that contaminant concentrations were higher near the close metalliferous mine than downstream. Also, Ca-silicates comprise of minerals such as albite and calcian; $\mathrm{Mg}$-silicates include phlogopite-1M and illite while Fe-silicates include hematite. It was also noted that the average $\mathrm{pH}$ of 3.0 and $\mathrm{Eh}$ of $492 \mathrm{mV}$, which favoured hematite over goethite weathering, as observed in the study of Schwertmann [41] are pronounced in the presence of clay minerals [41], as observed in this study.

The average $\mathrm{pH}$ and $\mathrm{Eh}$ values for midstream values were from 3.4 and $518 \mathrm{mV}$, respectively with $\mathrm{SiO}_{2}$ and $\mathrm{K}_{2} \mathrm{O}$ decreasing to 53.8 and 1.72 (wt.\%), respectively; while $\mathrm{Al}_{2} \mathrm{O}_{3}$ and $\mathrm{Fe}_{2} \mathrm{O}_{3}$ increased to 14.9 and 10.6 (wt.\%), respectively; a phenomena attributed to the wash-out effect of the suspended solids by mostly wind rather than moisture erosion, even when the samples were collected during the wet season. Such observations were also supported by the slope of the waste rock heap dump, which is not vegetated, further supporting waste heap weathering processes due to climatic conditions in this arid region. Additionally, acidity of the soil samples increases with the mobilisation of PTEs in soils, as some are potentially acid forming, posing a risk of acid metalliferous drainage (AMD) [42-51] formation in this area after washed out event and subsequent contamination of groundwater [21].

The average concentration of $\mathrm{Pb}, \mathrm{Zn}, \mathrm{Cu}, \mathrm{Ni}, \mathrm{Cr}, \mathrm{Co}, \mathrm{V}$ and $\mathrm{S}$ decreased in the midstream samples to $(\mathrm{mg} / \mathrm{kg}) 53.2,74.5$, 1090, 39.9, 98.0, 26.9 and 90.4 and 2613, respectively; while the averaged concentrations of $\mathrm{Mn}, \mathrm{F}$, and $\mathrm{Cl}$ increased, i.e., to (kg/mg): 613, 1424 and 143, respectively. This could be the consequence of a large quantity of mine waste heaps near midstream sampling site, with further PTE distribution due to anthropogenic activities and persistent wind conditions. The $\mathrm{Pb}$, $\mathrm{Cu}, \mathrm{Cr}$ and $\mathrm{F}$ concentrations were also not within the SSV in the midstream samples, while high concentration of $\mathrm{Cr}$ in the midstream samples could be ascribed to trans-boundary chromium discharge in drains from mine waste heaps in to the area; an indication that $\mathrm{Cr}$ leached into the subsoil. The $\mathrm{Cr}$ percolation may vary through the processes of reduction and oxidation than other PTEs [52]. PTEs found in the midstream samples were in the order of $\mathrm{S}>\mathrm{F}>\mathrm{Cu}>\mathrm{Mn}$. and These metals are important to monitor since they are capable of decreased vegetation due to the risk of bioaccumulation which will further facilitate soil erosion and possibly lead to groundwater contamination [21, 53]. Similar results were obtained by Moncho et al. [8] while predicting metals bioavailability in the top-soils in O'Kiep.
For the downstream samples, the $\mathrm{pH}$ was 3.8 while the Eh was $531 \mathrm{mV}$, respectively. Further decrease of the concentrations of PTEs $\mathrm{Pb}, \mathrm{Zn}, \mathrm{Cu}, \mathrm{Ni}, \mathrm{Co}, \mathrm{Mn}, \mathrm{Cr}, \mathrm{V}, \mathrm{F}, \mathrm{S}$ and $\mathrm{Cl}$, was recorded $(\mathrm{mg} / \mathrm{kg}): 52.8,124.5,503,24.8,13.0,298$, 59.5, 51.0, 610, 678 and 116; respectively; the concentrations of $\mathrm{Pb}, \mathrm{Cu}, \mathrm{Cr}$ and $\mathrm{F}$ were however all above the SSV, while the concentrations of $\mathrm{Zn}, \mathrm{Ni}, \mathrm{Co}, \mathrm{Mn}, \mathrm{V}, \mathrm{S}$ and $\mathrm{Cl}$ were within the SSV guidelines. The solubility of the PTEs that can occur as free hydrated cations generally increases with decreasing $\mathrm{pH}$ [34]. Generally, the excessive concentration of PTEs in O'Kiep may lead to elevated potential risks to human health and the local environment [53] including any groundwater sources. Metals in soil can be adsorbed onto specific sites at low concentrations. It is hypothesised that little rainfall as experienced in O'Kiep can result in very limited percolation thus accumulation of salts, including the PTEs [16].

However, the content of the mobile fractions depends on the soil texture and characteristics [54]. The presence of $\mathrm{Co}, \mathrm{Ni}, \mathrm{Zn}$, $\mathrm{Co}, \mathrm{Cr}$ and $\mathrm{V}$ is associated with ilmenite and $\mathrm{Ni}, \mathrm{Cr}, \mathrm{F}$ associated with magnetite, which are the most common minerals in O'Kiep and they weather easily [55]. On the other hand, the presence of $\mathrm{V}, \mathrm{Zn}, \mathrm{Cu}, \mathrm{Ni}$ and $\mathrm{Co}$, are assorted with biotite and apatite; however, these PTEs are unusual and forms a significant example of magmatic sulphide conglomerates found in O'Kiep [56] and other surrounding areas of Namaqualand. These results are similar to those reported in a study by Rozendaal and Horn [10], which focussed on the slag chemistry of the O'Kiep soil.

\section{CONCLUSION}

This study has provided an important reference information for the vulnerability of soils with regard to PTE mobility thus contamination from mine waste heap and mining activity in O'Kiep. The soils in O'Kiep are highly contaminated with average $\mathrm{pH}$ and $\mathrm{Eh}$ of 3.4 and $518 \mathrm{mV}$, respectively, with the most abundant potential toxic elements (PTEs) being (mg/kg): S (2965), Cu (1455), F (1125), Mn (425), Cl (133), Zn (97), Cr (87), V (80), Pb (67, Ni (45) and Co (28). The lower the pH, the higher the mobility of the PTEs. The extent of soil contamination and its effect on surrounding agro-ecosystems, all the way to the food chain, have received limited attention in O'kiep. The bioaccumulation of these PTEs in food crops or even in vegetation, has never being explored, but as observed from various literature sources, it can cause long-term cumulative human and environmental health effects, as other diseases related to heavy metal contamination can ensue especially when these concentrations exceeds the Soil Screening Values levels. Currently, the elevated mobility and bioavailability of PTEs in soils of O'Kiep are of great concern in the area. The adequate protection and restoration of soil ecosystems contaminated by PTEs require remedial procedures especially in O'Kiep, whereby risk of groundwater contamination is high.

\section{ACKNOWLEDGMENT}

Authors would like to thank Mr Frikkie Masson for his assistance with soil sampling. 


\section{REFERENCES}

[1] T. Chen, J. Wong, H. Zhou, and M. Wong, "Assessment of trace metal distribution and contamination in surface soils of Hong Kong," Environmental Pollution, vol. 96, pp. 61-68, 1997. https://doi.org/10.1016/S0269-7491(97)00003-1

[2] K. Naicker, E. Cukrowska, and T. McCarthy, "Acid mine drainage arising from gold mining activity in Johannesburg, South Africa and environs," Environmental Pollution, vol. 122, pp. 29-40, 2003. https://doi.org/10.1016/S0269-7491(02)00281-6

[3] E. Fosso-Kankeu, A. Manyatshe, A. Munyai, and F. Waanders, "AMD formation and dispersion of inorganic pollutants along the main stream in a mining area," presented at the Mining Meets Water - Conflicts and Solutions, Freiberg/Germany (TU Bergakademie Freiberg). 2016.

[4] L. A. Bizzi, "Diamond exploration: fundamentals and opportunities in South America," Revista Brasileira de Geociências, vol. 31, pp. 631-634, 2017.

https://doi.org/10.25249/0375-7536.2001314631634

[5] M. Yuhara, H. Kagami, and N. Tsuchiya, "Rb-Sr and Sm-Nd systematics of granitic and metamorphic rocks in the Namaqualand Metamorphic Complex, South Africa: Implications for evolution of marginal part of Kaapvaal craton," 2001.

[6] M. Rashed, "Monitoring of contaminated toxic and heavy metals, from mine tailings through age accumulation, in soil and some wild plants at Southeast Egypt," Journal of Hazardous Materials, vol. 178, pp. 739-746, 2010. https://doi.org/10.1016/j.jhazmat.2010.01.147

[7] E. Fosso-Kankeu, R. Kaitano, F. Waanders, and A. Mulaba-Bafubiandi, "Soil quality in the basin of mine effluents and the potential of alleviation of metal dispersion," presented at the An Interdisciplinary Response to Mine Water Challenges - Sui, Sun \& Wang (eds) China University of Mining and Technology Press, Xuzhou, 2014.

[8] T. Moncho, I. Erdogan, M. Emandien, S. Ntwampe, E. Fosso-Kankeu, F. Waanders, et al., "Prediction of Metals Bioavailability in the Soils of O’Kiep, South Africa," Midstream, vol. 29, p. 17.879916, 2017.

[9] E. Sakala, F. Fourie, M. Gomo, and H. Coetzee, "Hydrogeological investigation of the Witbank, Ermelo and Highveld Coalfields: Implications for the subsurface transport and attenuation of acid mine drainage."

[10] A. Rozendaal and R. Horn, "Textural, mineralogical and chemical characteristics of copper reverb furnace smelter slag of the Okiep Copper District, South Africa," Minerals Engineering, vol. 52, pp. 184-190, 2013. https://doi.org/10.1016/j.mineng.2013.06.020

[11] A. Gałuszka, Z. M. Migaszewski, S. Dołęgowska, A. Michalik, and A. Duczmal-Czernikiewicz, "Geochemical background of potentially toxic trace elements in soils of the historic copper mining area: a case study from Miedzianka Mt., Holy Cross Mountains, south-central Poland," Environmental Earth Sciences, vol. 74, pp. 4589-4605, 2015. https://doi.org/10.1007/s12665-015-4395-6

[12] F. Nannoni, G. Protano, and F. Riccobono, "Fractionation and geochemical mobility of heavy elements in soils of a mining area in northern Kosovo," Geoderma, vol. 161, pp. 63-73, 2011. https://doi.org/10.1016/j.geoderma.2010.12.008

[13] B. Cairncross, "History of the THE OKIEP COPPER DISTRICT Namaqualand, Northern Cape Province South Africa," Mineralogical Record, vol. 35, p. 289, 2004.

[14] J. Raith and H. Stein, "Re-Os dating and sulfur isotope composition of molybdenite from tungsten deposits in western Namaqualand, South Africa: implications for ore genesis and the timing of metamorphism," Mineralium Deposita, vol. 35, pp. 741-753, 2000. https://doi.org/10.1007/s001260050276

[15] M. García-Lorenzo, C. Pérez-Sirvent, M. Martínez-Sánchez, and J. Molina-Ruiz, "Trace elements contamination in an abandoned mining site in a semiarid zone," Journal of Geochemical Exploration, vol. 113, pp. 23-35, 2012 https://doi.org/10.1016/j.gexplo.2011.07.001

[16] S. Earle, Physical geology. Campus Manitoba.: Campus Manitoba, 2016.

[17] T. Moncho, I. Erdogan, M. Emandien, S. Ntwampe, E. Fosso-Kankeu, F. Waanders, et al., "Prediction of Metals Bioavailability in the Soils of O'kiep, South Africa," in 9th International Conference on Advances in Science, Engineering, Technology and Waste Management (ASETWM-17), 2017.
[18] G. Gadd, "Transformation and mobilization of metals, metalloids, and radionuclides by microorganisms," Biophysico-chemical processes of heavy metals and metalloids in soil environments. Wiley, Hoboken, pp. 53-96, 2007. https://doi.org/10.1002/9780470175484.ch2

[19] A. Violante, V. Cozzolino, L. Perelomov, A. Caporale, and M. Pigna, "Mobility and bioavailability of heavy metals and metalloids in soil environments," Journal of Soil Science and Plant Nutrition, vol. 10, pp. 268-292, 2010. https://doi.org/10.4067/S0718-95162010000100005

[20] I. H. Smuts, "Influence of Acid Mine Drainage on the soils of Nababeep, Namaqualand with reference to soil chemistry, minerals and metal mobility," Stellenbosch: Stellenbosch University, 2015.

[21] I. Erdogan, T. Moncho, E. Fosso-Kankeu, S. Ntwampe, F. Waanders, N. Hoth, et al., "Hydrochemical Characteristics of Open-Pit Groundwater from a Closed Metalliferous Mine in O'kiep, Namaqualand Region, South Africa," in 9th Int'l Conference on Advances in Science, Engineering, Technology \& Waste Management (ASETWM-17) Nov. 27-28, 2017 Parys, South Africa, 2017, pp. 64-68

[22] E. G. Gregorich and M. R. Carter, Soil sampling and methods of analysis: CRC Press, 2007.

[23] P. J. Schoeneberger, Field book for describing and sampling soils: Government Printing Office, 2012.

[24] H. Meuser, Contaminated urban soils vol. 18: Springer Science \& Business Media, 2010. https://doi.org/10.1007/978-90-481-9328-8

[25] R. B. Ferguson, G. W. Hergert, C. A. Shapiro, and C. S. Wortmann, "Guidelines for soil sampling," NebGuide G1740, University of Nebraska-Lincoln, USA, 2007.

[26] J. Anderson and J. Ingram, "A handbook of methods," CAB International, Wallingford, Oxfordshire, vol. 221, 1993.

[27] M. Fey, "A short guide to the soils of South Africa, their distribution and correlation with World Reference Base soil groups," in Proceedings, 2010, pp. 32-35.

[28] A. A. Sobek, Field and laboratory methods applicable to overburdens and minesoils: Industrial Environmental Research Laboratory, Office of Research and Development, US Environmental Protection Agency, 1978.

[29] B. Beckhoff, B. Kanngießer, N. Langhoff, R. Wedell, and H. Wolff, Handbook of practical X-ray fluorescence analysis: Springer Science \& Business Media, 2007.

[30] J. S. Compton, R. A. White, and M. Smith, "Rare earth element behavior in soils and salt pan sediments of a semi-arid granitic terrain in the Western Cape, South Africa," Chemical Geology, vol. 201, pp. 239-255, 2003. https://doi.org/10.1016/S0009-2541(03)00239-0

[31] N. E. M. Government of South Africa and G. P. Act (No. 107), Pretoria, "National Environmental Management: Waste Act 59 of 2008," D. o. E. Affairs, Ed., ed. Pretoria: Government Gazzette, 2008.

[32] M. Amponsah-Dacosta and D. L. Reid, "Mineralogical characterization of selected south african mine tailings for the purpose of mineral carbonation," An Interdisciplinary Response to Mine Water Challenges; Sui, W., Sun, Y., Wang, C., Eds, pp. 686-692, 2014.

[33] X. Kong, T. Tian, S. Xue, W. Hartley, L. Huang, C. Wu, et al., "Development of alkaline electrochemical characteristics demonstrates soil formation in bauxite residue undergoing natural rehabilitation," Land Degradation \& Development, vol. 29, pp. 58-67, 2018. https://doi.org/10.1002/ldr.2836

[34] P. Hooda, Trace elements in soils: John Wiley \& Sons, 2010. https://doi.org/10.1002/9781444319477

[35] M. Gitari, S. Akinyemi, R. Thobakgale, P. Ngoejana, L. Ramugondo, M. Matidza, et al., "Physicochemical and mineralogical characterization of Musina mine copper and New Union gold mine tailings: Implications for fabrication of beneficial geopolymeric construction materials," Journal of African Earth Sciences, vol. 137, pp. 218-228, 2018. https://doi.org/10.1016/j.jafrearsci.2017.10.016

[36] J. Glinski, Soil Physical Conditions and Plant Roots: 0. New York: CRC press, 2018. https://doi.org/10.1201/9781351076708

[37] A. van der Ent and M. Edraki, "Environmental geochemistry of the abandoned Mamut Copper Mine (Sabah) Malaysia," Environmental Geochemistry and Health, vol. 40, pp. 189-207, 2018.

https://doi.org/10.1007/s10653-016-9892-3 
[38] C. A. J. Appelo and D. Postma, Geochemistry, Groundwater and Pollution: CRC press, 2004.

[39] T. N. Clifford and E. S. Barton, "The O'okiep Copper District, Namaqualand, South Africa: a review of the geology with emphasis on the petrogenesis of the cupriferous Koperberg Suite," Mineralium Deposita, vol. 47, pp. 837-857, 2012. https://doi.org/10.1007/s00126-012-0403-x

[40] N. Soltani, B. Keshavarzi, F. Moore, A. Sorooshian, and M. R. Ahmadi, "Distribution of potentially toxic elements (PTEs) in tailings, soils, and plants around Gol-E-Gohar iron mine, a case study in Iran," Environmental Science and Pollution Research, vol. 24, pp. 18798-18816, 2017. https://doi.org/10.1007/s11356-017-9342-5

[41] U. Schwertmann, J. Friedl, H. Stanjek, and D. Schulze, "The effect of clay minerals on the formation of goethite and hematite from ferrihydrite after 16 years' ageing at $25 \mathrm{C}$ and $\mathrm{pH}$ 4-7," Clay Minerals, vol. 35, pp. 613-623, 2000 . https://doi.org/10.1180/000985500547034

[42] E. Fosso-Kankeu, A. Mulaba-Bafubiandi, B.B. Mamba, T.G. Barnard, Assessing the effectiveness of a biological recovery of nickel from tailings dumps. Journal of Minerals Engineering. Vol. 24, pp. 470-472, 2011. https://doi.org/10.1016/j.mineng.2010.11.007

[43] E. Fosso-Kankeu, F. Waanders, A.F. Mulaba-Bafubiandi and S. Sidu, Leachability of suspended particles in mine water and risk of water contamination. $10^{\text {th }}$ ICARD/IMWA 2015; $10^{\text {th }}$ International Conference on Acid Rock Drainage \& IMWA Annual Conference. 21-24 April 2015 Santiago-Chile. Editors: Adrian Brown, Charles Bucknam, Joanna Burgess, Manuel Carballo, Devin Castendyk, Linda Figueroa, Lisa Kirk, Virginia McLemore, James McPhee, Mike O'Kane, Robert Seal, Jacques Wiertz, David Williams, Ward Wilson, Christian Wolkersdorfer. ISBN: 978-956-9393-28-0. Chap 4. Pp 1-9. 2015.

[44] E. Fosso-Kankeu, F.B. Waanders, and A.H. Munyai, Susceptibility of Metals Release from Tailings Dumps Located In the Krugersdorp Area. $7^{\text {th }}$ International Conference on Latest Trends in Engineering and Technology (ICLTET' 2015), November 26-27, 2015 Irene, Pretoria (South Africa). Editors: E. Muzenda and T Yingthawornsuk. ISBN: 978-93-84422-58-5. 2015.

[45] E. Fosso-Kankeu, F. Waanders, and W. Botes, Recovery of Base Metals from Mine Tailings Dumps collected in the Vicinity of Potchefstroom: Leaching assisted by Complexing Agent. $7^{\text {th }}$ International Conference on Latest Trends in Engineering and Technology (ICLTET' 2015), November 26-27, 2015 Irene, Pretoria (South Africa). Editors: E. Muzenda and T Yingthawornsuk. ISBN: 978-93-84422-58-5. 2015.

[46] A.H. Munyai, E. Fosso-Kankeu, F. Waanders, Effects of organic acids on heavy metals released from mine tailings. International Conference on Advances in Science, Engineering, Technology and Natural Resources (ICASETNR-16) Nov. 24-25, 2016, Parys - South Africa. ISBN: 978-93-84468-79-8. 2016.

[47] E. Fosso-Kankeu, Investigation of the oxidation rate of sediments from AMD using humidity cell test. International Conference on Advances in Science, Engineering, Technology and Natural Resources (ICASETNR-16) Nov. 24-25, 2016, Parys - South Africa. ISBN: 978-93-84468-79-8. 2016.

[48] A.H. Munyai, E. Fosso-Kankeu, F. Waanders, Mobility of metals from mine tailings using different types of organic acids: Batch leaching experiment. International Journal of Science and Research. Vol. 5, pp. 520-527, 2016.

[49] E. Fosso-Kankeu, B. Barlow, N. Lemmer and F. Waanders, Geochemical speciation of metal ions in the leachate of tailings treated with synthetic rain water. $9^{\text {th }}$ Int'l Conference on Advances in Science, Engineering, Technology \& Waste Management (ASETWM-17). 27-28 November 2017, Parys, South Africa. Award winning paper. Editors: F. Waanders, E. Fosso-Kankeu, B. Topcuoglu, M. Plaisent, Y. Thaweesak. ISBN: 978-81-934174-6-1. Pp. 19-23. 2017.

[50] E. Fosso-Kankeu, A. Manyatshe, F. Waanders, Mobility potential of metals in acid mine drainage occurring in the Highveld area of Mpumalanga Province in South Africa: Implication of sediments and efflorescent crusts. International Biodeterioration and Biodegradation. Vol. 119, pp. 661-670, 2017.

https://doi.org/10.1016/j.ibiod.2016.09.018
[51] E. Fosso-Kankeu and J. Redelinghuys, Bacterial ecology of biofilms sustaining pollution by acid mine drainage near mining areas in Mpumalanga Province - South Africa. $11^{\text {th }}$ ICARD/IMWA/MWD Conference "Risk to Opportunity". 10-14 September 2018 Pretoria, South Africa. C. Wolkersdorfer, L. Sartz, A. Weber, J. Burgess, G. Tremblay.ISBN: 978-0-620-80650-3 Vol 1 (2 volumes). 2018.

[52] M. Malandrino, O. Abollino, S. Buoso, A. Giacomino, C. La Gioia, and E. Mentasti, "Accumulation of heavy metals from contaminated soil to plants and evaluation of soil remediation by vermiculite," Chemosphere, vol. 82, pp. 169-178, 2011. https://doi.org/10.1016/j.chemosphere.2010.10.028

[53] R. A. Wuana and F. E. Okieimen, "Heavy metals in contaminated soils: a review of sources, chemistry, risks and best available strategies for remediation," Isrn Ecology, vol. 2011, 2011.

[54] J. Agnieszka and G. Barbara, "Chromium, nickel and vanadium mobility in soils derived from fluvioglacial sands," Journal of hazardous materials, vol. 237, pp. 315-322, 2012. https://doi.org/10.1016/j.jhazmat.2012.08.048

[55] H. Bradl, Heavy metals in the environment: Origin, Interaction and Remediation vol. 6: Elsevier, 2005.

[56] J. Morgan, H. Stein, J. Hannah, R. Markey, and J. Wiszniewska, "Re-Os study of Fe-Ti-V oxide and $\mathrm{Fe}-\mathrm{Cu}-\mathrm{Ni}$ sulfide deposits, Suwałki Anorthosite Massif, northeast Poland," Mineralium Deposita, vol. 35, pp. 391-401, 2000 https://doi.org/10.1007/s001260050251

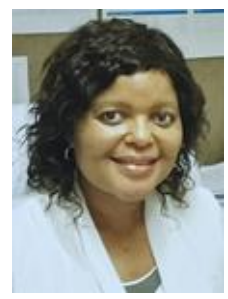

Ms. Innocentia Erdogan is currently a Lecturer at Cape Peninsula University of Technology in the Department of Chemical Engineering and graduated with a Master's Degree in Chemical Engineering. Her Masters' dissert ation looked at the application of membrane technology with an integrated anaerobic / aerobic reactor for the treatment of beverage industry for recycle and to meet municipal wastewater discharged standards. Innocentia is also a $\mathrm{PhD}$ candidate at the School of Chemical and Minerals Engineering, North West University. Her $\mathrm{PhD}$ focuses on species dispersion form a metalliferous mine by looking at developing a geochemical predictive model for acid mine drainage from waste rock associated with metal mining and biological passive remediation techniques to reduce the pollutants in acid mine drainage. 